Ann. rheum. Dis. (1961), 20, 369.

\title{
STUDIES ON THE ISOLATION OF RHEUMATOID FACTOR
}

\author{
BY \\ K. JAMES, ${ }^{*}$ D. FELIX-DAVIES, AND D. R. STANWORTH \\ Department of Experimental Pathology, Medical School, Birmingham
}

The need for the isolation of rheumatoid factor in a high state of purity and in sufficient quantity for antiserum production has led to an appraisal of the various purification methods available.

Ziff, Brown, Lospalluto, Badin, and McEwen (1956) demonstrated that the sensitized sheep cell agglutinating activity of rheumatoid serum was precipitated in the euglobulin fraction, and Svartz and Schlossmann (1954) showed that this factor precipitated in the "cold globulin" fraction and were thus able to obtain a serologically active but heterogenous concentrate.

Later, both these groups of workers applied the cellulose ion exchange resins, diethylaminoethyl and carboyxmethyl cellulose, developed by Peterson and Sober (1956) to further fractionate euglobulin fractions (Lospalluto and Ziff, 1959; Svartz, Carlson, Schlossmann, and Ehrenberg, 1958).

Ultracentrifugal studies of rheumatoid sera and euglobulin fractions showed that the factor circulated as a high molecular weight component of sedimentation coefficient 19 or $22 \mathrm{~S}$ and this property has been used by Kunkel, Franklin, and MullerEberhard (1959) and Heimer, Federico, and Freyberg (1958) to separate rheumatoid factor from lower molecular weight proteins. Most of these workers were able to obtain reasonably pure $19 \mathrm{~S}$ globulin with a considerable concentration of serological activity. In these investigations, however, little attention was paid to immunochemical analyses of individual proteins, and the relative merits in each step in the concentration of rheumatoid factor were not determined.

In the investigations now reported, an attempt has been made to determine the most efficient procedure available for the isolation of rheumatoid factor in a relatively pure form. The recovery of rheumatoid factor activity has been measured after each pro-

\footnotetext{
- In receipt of a Medical Research Council Studentship for training in research methods.
}

cedure by the Rose-Waaler sensitized sheep cell technique, and the fractionation achieved has been assessed by total protein estimation, ultracentrifugal, immunochemical, and immuno-electrophoretic analyses. In this way it has been possible to make a critical comparison of the effectiveness and deficiencies of the different methods of purification. These methods included euglobulin precipitation to obtain a crude concentrate of rheumatoid factor, followed by diethylaminoethyl cellulose chromatography, zone centrifugation, and Cohn low-temperature ethanol fractionations in various orders and combinations.

Some of the difficulties encountered are discussed below; they include serious loss of serological activity as well as low degree of isolation in some protein preparations.

\section{Materials and Methods}

\section{Rheumatoid Sera}

Sera were obtained from ten patients with classical active rheumatoid disease, selected because they had the highest Rose-Waaler sensitized sheep cell agglutination titre of those available at the time; this titre ranged between $1 / 1,024$ and $1 / 5,000$ in half the patients; exceptionally a serum with a titre as low as $1 / 64$ or as high as $1 / 12,600$ had to be used. There were seven male and three female patients, aged 40 to 67 years, with a 4 to 32-year history of rheumatoid arthritis.

\section{Estimation of Protein Concentration}

The modification of the Folin-Ciocalteau method developed by Lowry, Rosebrough, Farr, and Randall (1951) was usually employed, using a bovine serum albumin standard.

\section{Measurement of Rheumatoid Factor Activity}

The rheumatoid factor was assayed by Ball's modification of the sensitized sheep cell agglutination test of Rose-Waaler (Ball, 1950), but using one-third of an 
agglutinating dose for sensitization and studying the pattern of sedimentation in plastic cups as the index of agglutination. Units of serological activity have been calculated by multiplying the volume of the sample by the reciprocal of its Rose-Waaler titre. Specific activities are derived by dividing the reciprocal of the Rose-Waaler titre by the protein concentration in $\mathrm{mg} . / \mathrm{ml}$. and is equivalent to the maximum volume ( $\mathrm{ml}$.) to which $1 \mathrm{mg}$. protein can be diluted and still give a positive Rose-Waaler titre.

\section{Euglobulin Precipitation}

Crude protein precipitates rich in rheumatoid factor activity were obtained by lowering the ionic strength of the serum in various ways, involving dilution with, or dialysis against, water (as described in Table III). On two occasions precipitation with 33 per cent. saturated ammonium sulphate was used after failure to precipitate rheumatoid factor activity by dialysis.

\section{Ion Exchange Chromatography}

Chromatography in columns $(20 \mathrm{~cm}$. high, $1 \cdot 1 \mathrm{~cm}$. diameter) of DEAE cellulose, prepared according to the method described by Peterson and Sober (1956), was performed by step-wise elution in a manner essentially similar to that employed by those workers (Sober, Gutter, Wyckoff, and Peterson, 1956). DEAE cellulose chromatography was preferred to chromatography on carboxymethyl cellulose (CM), as applied by Fallet, Lospalluto, and Ziff (1958), because of the superior resolving power of the former method in relation to 19S $\gamma$ globulin.*

In some cases, however, $0.05 \mathrm{M} \mathrm{NaH}_{2} \mathrm{PO}_{4}$ solution containing $0.15 \mathrm{M} \mathrm{NaCl}$ was used as a final eluent in order to remove the 19S $\gamma$ globulin in a sharp band.

"Batch" chromatography on DEAE cellulose was carried out by a modification of the method recently described by Stanworth (1960), using filtration instead of centrifugation and with suitable washing $(\mathrm{pH}$ greater than 5 and ionic strength $0.05 \mathrm{M}$ ) and eluting solutions $(1.5 \mathrm{M} \mathrm{NaCl})$.

\section{Cohn Low-temperature Ethanol Fractionation}

A small-scale fractionation procedure designed to use 5-ml. volumes of plasma was employed. This was a modification of "Method 10" of Lever, Gurd, Uroma, Brown, Barnes, Schmid, and Schultz (1951), developed by Dr. K. W. Walton. It involved the adjustment of the $\mathrm{pH}$ of the sample to 7.4 with $0.01 \mathrm{M} \mathrm{NaOH}$ before the initial precipitation, and it provided a rapid means of separating the $\gamma$-globulins from other serum protein constituents.

* This is the high molecular weight component of normal serum which is associated with iso-agglutinin activity and is termed $\mathbf{B}_{2} \mathbf{M}$ by Grabar and Williams (1955), on the basis of the position of its precipitin line in the serum immuno-electrophoretic pattern. Other synonyms include the term "Iota" protein used by Stanworth (1959) and the $\gamma_{1}$ macroglobulin described by Kunkel (1960). In this paper it will be constantly referred to as $19 \mathrm{~S} \gamma$; it is not suggested that it is identical with rheumatoid factor.

\section{Zone Centrifugation}

Fractionations by this procedure were achieved by centrifuging 1-ml. samples in buffered sucrose gradients $\frac{?}{?}$. in lusteroid tubes (5-ml. capacity) at 39,000 r.p.m. and $\Rightarrow$ $12.5^{\circ} \mathrm{C}$. in a Spinco SW 39 rotor for $7 \mathrm{hrs}$. This is a $\stackrel{?}{\rightarrow}$ modification of the method used by Kunkel and others? (1959) in the fractionation of 19S serum proteins $\underline{ }$ (Stanworth, James, and Squire, 1961). Spinco No. $40 \frac{\mathrm{m}}{\frac{6}{6}}$ angle rotors were also used on two occasions.

\section{Analytical Ultracentrifugation}

Analyses were carried out in 12-mm. cells in a Spinco Model E machine at 60,000 r.p.m. and $20^{\circ}$ C. Samples $\vec{\omega}$ (1-ml.) were pre-dialysed for $16 \mathrm{hrs}$ against $1 \mathrm{~L}$. barbitone $\stackrel{\circ}{ }$ buffer $(\mathrm{pH} 8.6 ; \mathrm{I}=0.05)$ containing $0.2 \mathrm{M} \mathrm{NaCl}$, or phosphate buffer pH 6.9; $\mathrm{M}=0.06+15 \mathrm{M} \mathrm{NaCl}$.

\section{Concentration of Protein Solutions}

Details of the ultrafiltration and carbowax (poly- $\overparen{\mathcal{C}}$ ethylene glycol) methods used are given in Table VI.

\section{Quantitative Gel-diffusion Precipitin Analysis}

Estimations were carried out by Dr. J. F. Soothill, using the technique developed by Gell (1957). Three specific antisera were used. One was against $7 \mathrm{~S} \gamma \stackrel{\mathbb{C}}{-}$ globulin, and one against high molecular weight $\alpha_{2} \vec{\odot}$ glycoprotein ( $\alpha_{2}$ macroglobulin of Kunkel). The o⿺ against 19S $\gamma$ globulin was raised with a macroglobulm. from the serum of a patient with macroglobulinaenfis and was absorbed with $7 \mathrm{~S} \gamma$ globulin and hypogammatglobulinaemic serum; this antiserum successfully measures 19S $\gamma$ globulin. Further details of these antisera are reported by Soothill (to be published). The results for $\frac{\mathrm{Q}}{\mathcal{Q}}$ $7 \mathrm{~S} \gamma$ are obtained as $\mathrm{mg} . / 100 \mathrm{ml}$. The results for the other two proteins were obtained as a percentage of the $\overrightarrow{\overrightarrow{0}}$ concentration in a standard serum from a healthy adult 3 male. For calculation purposes, arbitrary conversion factors to $\mathrm{mg} . / 100 \mathrm{ml}$. were used. These are 100 per? cent. $\alpha_{2}=100 \mathrm{mg} . / \mathrm{ml}$., and 100 per cent. $19 \mathrm{~S} \gamma=$ $50 \mathrm{mg} . / \mathrm{ml}$.

\section{Immuno-electrophoresis}

Analyses were carried out in buffered agar according to the technique of Grabar and Williams (1955).

\section{Results}

The properties of the ten rheumatoid sera used $N$ for serial fractionation procedures are shown in $\tilde{N}$ Table I (opposite).

As already mentioned, the Rose-Waaler titres 0 were variable, so that the specific activity also varied from 1.8 to $146 \mathrm{ml} . / \mathrm{mg}$. In Table I the compositions of these sera are also shown in terms $\stackrel{\Phi}{?}$ of ultracentrifugal and immunological analyses; these are given mainly for comparison with the 
TABLE I

PROPERTIES OF RHEUMATOID SERA USED

\begin{tabular}{|c|c|c|c|c|c|c|c|c|c|c|c|}
\hline \multirow{2}{*}{$\begin{array}{l}\text { Case } \\
\text { No. }\end{array}$} & \multirow{2}{*}{ Sex } & \multirow{2}{*}{$\begin{array}{c}\text { Protein } \\
\text { Concen- } \\
\text { tration } \\
(\mathrm{mg} . / 100 \mathrm{ml} .)\end{array}$} & \multirow{2}{*}{$\begin{array}{c}\text { Specific } \\
\text { Activity } \\
\text { (ml. }+/ \mathrm{mg} .)\end{array}$} & \multicolumn{5}{|c|}{$\begin{array}{l}\text { Ultracentrifugal Composition } \\
\text { (mg./100 ml.) }\end{array}$} & \multicolumn{3}{|c|}{$\begin{array}{l}\text { Immunological Composition } \\
\text { (mg./100 ml.) }\end{array}$} \\
\hline & & & & $22 \mathrm{~S}$ & $19 S$ & $10 S$ & $7 \mathrm{~S}$ & $4 \cdot 5 S$ & $\alpha_{2} *$ & $19 S \gamma^{*}$ & $7 S \gamma$ \\
\hline 1 & $\mathbf{F}$ & $3,700 \dagger$ & $1 \cdot 8$ & - & 130 & - & 840 & 2,730 & \multicolumn{3}{|c|}{ Not determined } \\
\hline 2 & $\mathbf{F}$ & 7,700 & $9 \cdot 4$ & 一 & 150 & - & 420 & 7,130 & \multicolumn{3}{|c|}{ Not determined } \\
\hline 3 & $\mathbf{M}$ & 7,800 & 106 & 80 & 170 & 120 & 730 & 6,700 & 56 & 100 & 750 \\
\hline 4 & $\mathbf{M}$ & 7,500 & $6 \cdot 8$ & - & 135 & - & 900 & 6,460 & 88 & 150 & 960 \\
\hline 5 & $\mathbf{F}$ & 10,900 & 24 & 一 & 390 & - & 1,910 & 8,600 & 200 & 200 & 4,480 \\
\hline 6 & $\mathbf{M}$ & 8,100 & 63 & - & 100 & - & 1,000 & 7,000 & 75 & 60 & 1,280 \\
\hline 7 & $\mathbf{M}$ & 7,700 & 33 & 110 & 180 & 一 & 670 & 6,740 & 150 & 150 & 1,920 \\
\hline 8 & $\mathbf{M}$ & 9,200 & 14 & - & 250 & 110 & 2,700 & 6,170 & 75 & 300 & 2,560 \\
\hline 9 & $\mathbf{M}$ & 8,750 & 146 & 450 & 340 & - & 1,200 & 6,760 & 150 & 125 & 1,120 \\
\hline 10 & $\mathbf{M}$ & 8,800 & $36 \cdot 4$ & 105 & 105 & 650 & 1,350 & 6,690 & 200 & 500 & 1,280 \\
\hline \multicolumn{2}{|c|}{ S.D. Rheumatoid } & $8,500 \pm 1,080$ & & & $202 \pm 107$ & & $1,220 \pm 700$ & $6,900 \pm 690$ & $124 \pm 52$ & $198 \pm 184$ & $1,794 \pm 390$ \\
\hline \multicolumn{2}{|c|}{ S.D. Normal } & & & & $170 \pm 56$ & & $1,170 \pm 290$ & $6,070 \pm 300 \mid$ & $107 \pm 26$ & $71 \pm 30$ & $1,240 \pm 250$ \\
\hline
\end{tabular}

- See p. 370.

† Serum from Case 1 had been diluted before use.

‡ Specific Activity = Reciprocal Rose-Waaler Titre $\div$ Protein Concentration (mg. $/ 100 \mathrm{ml}.)=(\mathrm{ml} . / \mathrm{mg}$.) $(\mathrm{see} \mathrm{p.} 370)$.

S.D. = Standard Deviation (excluding Serum 1 in the rheumatoid results).

Normal Serum: Ultracentrifugal results from eleven normal sera and average protein content at $7 \mathrm{~g}$. per cent. assumed. Immunological results from twenty normal sera.

composition of products, but it may be noted that there is a general tendency for raised levels of total 7S and 7S $\gamma$ and probably of 19S $\gamma$ globulins and high molecular weight $\alpha_{2}$ glycoproteins.

Full-scale fractionations were undertaken on ten rheumatoid sera, as summarized in Table II (overleaf), the ninth and tenth being undertaken after a full study of the results of the first eight. Considering Runs 1 to 8, gains in specific activity have been from only 3- to 29-fold (excluding Run 6). Since the rheumatoid factor is a $19 \mathrm{~S}$ protein, which, even in the serum with highest Rose-Waaler titre, only contributes 4 per cent. of the total protein, it could be expected that efficient zone centrifugation alone would give a 25-fold increase in specific activity and a "pure" 19S protein. However, as will be discussed later, efficient zone centrifugation of 20 to $100 \mathrm{ml}$. serum is not a practical proposition with the apparatus at our disposal, so some prior method of removing the bulk of contaminating proteins is advantageous.

The recovery of units has varied from 1 to 50 per cent., being below 15 per cent. in any procedure using column chromatography on DEAE cellulose. The final product constituted between 0.11 and 3 per cent. of the starting protein. If the recovery of units had been higher these results would have been more satisfactory. The yield of final product lay between 5 and $30 \mathrm{mg}$. except in Runs 3 and 7 (only a small-scale fractionation).

Only two preparations were judged free of $7 \mathrm{~S}$ protein by ultracentrifugal analysis, and these had traces of $7 \mathrm{~S} \gamma$ as measured by the very sensitive immunological technique (Runs 3 and 8).

The concentrations of activity obtained in Runs 1 to 8 could quite possibly have been achieved by an efficient euglobulin precipitation with subsequent zone ultracentrifugation, and judging from Run 4, with a large proportion of starting units recovered in the final product. Such a procedure was used in Runs 9A and B and in Run 10 where the gains in specific activity were 35-, 30-, and 38-fold respectively. The recovery of units in the actual products were 32,34 , and $36 \cdot 5$ per cent. respectively (though taking into account samples removed for analysis and less active fractions not included in the product, some 54 to 66 per cent. of the total starting units could be accounted for). The yields of products were $80,99 \cdot 5$, and $84 \mathrm{mg}$., which constituted 0.95 , $1 \cdot 15$, and 0.95 per cent. of the original protein. These products also contained 7S $\gamma$ globulin as revealed by immuno-electrophoresis and ultracentrifugal analysis (Figs 1 and 2, overleaf), but the bulk of the protein, i.e. 92 per cent. in Run 9A, 81 per cent. in Run 9B and 88 per cent. in Run 10, had a sedimentation coefficient of $19 \mathrm{~S}$ or greater. 
COMPOSITION, ACTIVITIES, AND YIELDS OF RHEUMATOID FAC

\begin{tabular}{|c|c|c|c|c|c|c|}
\hline \multirow[t]{2}{*}{$\begin{array}{l}\text { Run } \\
\text { No. }\end{array}$} & \multirow[t]{2}{*}{$\begin{array}{l}\text { Case } \\
\text { No. }\end{array}$} & \multicolumn{3}{|c|}{$\begin{array}{c}\text { Fractionation Procedure } \\
\text { (for details of steps see following tables) }\end{array}$} & \multirow{2}{*}{\multicolumn{2}{|c|}{$27 \mathrm{~S}-22 \mathrm{~S}: 18$}} \\
\hline & & Step 1 & Step 2 & Step 3 & & \\
\hline 1 & 1 & Euglobulin precipitation $1 / 1 \dagger$ & $\begin{array}{l}\text { DEAE cellulose column } \\
\text { chromatography }\end{array}$ & & - & - \\
\hline $2 \mathrm{I}$ & 2 & I Euglobulin precipitation 2/I & $\begin{array}{l}\text { DEAE cellulose column } \\
\text { chromatography }\end{array}$ & . & - & - \\
\hline II & & II Ammonium sulphate precipitation 2'II & $\begin{array}{l}\text { DEAE cellulose column } \\
\text { chromatography }\end{array}$ & & 一 & . \\
\hline 3 & 3 & Euglobulin precipitation $3 / \mathbf{I}$ & $\begin{array}{l}\text { DEAE cellulose column } \\
\text { chromatography }\end{array}$ & Zone centrifugation & - & - \\
\hline \multirow[t]{2}{*}{$4 \mathrm{~A}$} & \multirow[t]{2}{*}{4} & A Euglobulin precipitation $\mathbf{A} / \mathbf{I} \mathbf{a}+\mathbf{I b}$ & \multirow[t]{2}{*}{ Zone centrifugation } & & 170 & 250 \\
\hline & & B Euglobulin precipitation $\mathrm{B}_{i}^{\prime} \mathrm{I} \ldots$ II & & & 70 & 450 \\
\hline \multirow{3}{*}{$\begin{array}{r}5 A \\
B\end{array}$} & \multirow[t]{3}{*}{5} & A Euglobulin precipitation $5 ; \mathbf{I}$ & Zone centrifugation & & - & 30 \\
\hline & & \multirow[t]{2}{*}{$\left.\begin{array}{l}\text { B Euglobulin precipitation } \\
\text { Ammonium sulphate precipitation }\end{array}\right\} 5 / 11+$ III } & \multirow{2}{*}{$\begin{array}{l}\text { DEAE cellulose column } \\
\text { chromatography }\left\{\begin{array}{l}\text { F.III } \\
\text { F.IV }\end{array}\right.\end{array}$} & & - & 40 \\
\hline & & & & & - & 30 \\
\hline 6 & 6 & Zone centrifugation & $\begin{array}{l}\text { DEAE cellulose column } \\
\text { chromatography }\end{array}$ & & - & - \\
\hline $7 \mathbf{A}$ & \multirow[t]{2}{*}{7} & DEAE cellulose batch chromatography & $\begin{array}{l}\text { Cohn low-temperature } \\
\text { ethanol fractionation }\end{array}$ & \multirow[t]{2}{*}{$\begin{array}{l}\text { DEAE cellulose batch } \\
\text { chromatography }\end{array}$} & - & - \\
\hline B & & Cohn low-temperature ethanol fractionation & $\begin{array}{l}\text { DEAE cellulose batch } \\
\text { chromatography }\end{array}$ & & - & - \\
\hline 8 & 8 & DEAE cellulose batch chromatography & $\begin{array}{l}\text { Cohn low-temperature } \\
\text { ethanol fractionation }\end{array}$ & Zone centrifugation & - & ‥ \\
\hline \multirow{2}{*}{$\begin{array}{c}9 \mathbf{A t}^{+} \\
\mathbf{B}\end{array}$} & \multirow[t]{2}{*}{9} & \multirow{2}{*}{ Euglobulin precipitation } & \multirow{2}{*}{ Zone centrifugation $\quad\left\{\begin{array}{l}\text { A } \\
\text { B }\end{array}\right.$} & & 115 & $210 \underset{?}{\supsetneq}$ \\
\hline & & & & & 190 & 910 \\
\hline $10 \mathrm{~A}$ & 10 & Euglobulin precipitation & Zone centrifugation & & & 15 \\
\hline
\end{tabular}

* See p. $370 . \quad+$ Euglobulin precipitation.

See Table III, e.g. 1/I for Run 1, Euglobulin precipitate I.

\section{Euglobulin Precipitation}

It has been the practice of various groups engaged in the study of rheumatoid factor to employ euglobulin precipitation as a first step (Svartz and Schlossmann, 1953; Kunkel and others, 1959; Lospalluto and Ziff, 1959). The crude precipitates thus obtained were found to contain most of the Rose-Waaler activity present in the original serum.

Euglobulin would therefore appear to be the most suitable starting material for the subsequent purification of rheumatoid factor. The composition of the euglobulin precipitated varied considerably, as did the efficiency of precipitating the rheumatoid factor without loss of activity (see Table III). These results suggest that there are uncontrolled factors involved in the precipitation of rheumatoid factor as water-insoluble euglobulin. One of these is undoubtedly the variability of the starting sera, all of which were obtained from different patients. In Serum 4B, almost all activity was precipitated after $24 \mathrm{hrs}$. while in Serum 5 very little had been precipitated after $48 \mathrm{hrs}$. Experiments recently performed show that, with Serum 5, the rheumatoid factor is efficiently recovered by diluting the serum 15 -fold with cold de-ionized water. The most critical factor in these experiments, however, would appear to be the ionic strength to which the rheumatoid sera were finally adjusted.

Trial experiments performed on Sera 9 and 10 showed that, as with Serum 5, Rose-Waaler activity was most efficiently precipitated ( 80 and 62.5 per cent. of the total) with minimum contamination from other proteins, by diluting the serum 15 -fold with cold de-ionized water at $4^{\circ} \mathrm{C}$. and centrifuging 


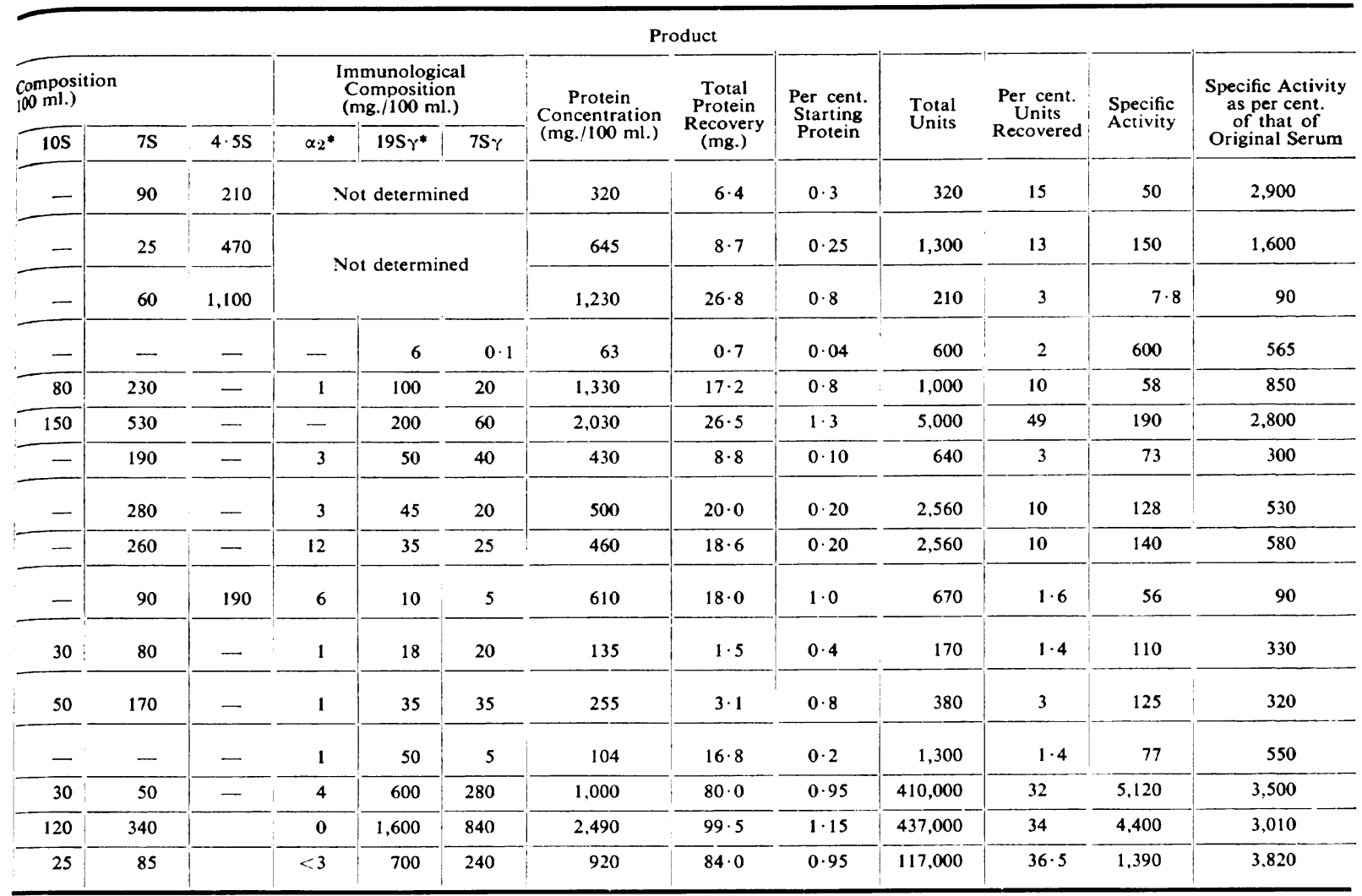

down the precipitate almost immediately. Precipitates obtained by dialysis on the other hand of these sera against 14 volumes of de-ionized water and centrifuging down the precipitates at 2,5 , and $24 \mathrm{hrs}$, each time redialysing the supernatant, were very heterogenous as compared with the precipitates obtained by dilution, and the combined precipitate contained only 31 and 12.5 per cent. of the original activity. The greater heterogeneity of the "dialysis" products as compared with the "dilution" products was well shown by immuno-electrophoresis (see Fig. 2). The water-dilution technique was therefore adopted in Fractionations 9 and 10; the euglobulin precipitation, after suspension in the minimum volume of phosphate $\mathrm{pH} 6.9 ; \mathrm{M}=0.06$ $+0.15 \mathrm{M} \mathrm{NaCl}$, was found to contain 70 and 44.4 per cent. of the original units (Table III). Washing of precipitates was avoided, for, as shown in Run 4 and other unpublished work, quite an appreciable amount of activity may be removed by cold distilled water.

The variability between different euglobulin preparations noted above led to more detailed studies of euglobulin and rheumatoid factor precipitation with a series of tests on only two different sera (Table IV). (In order to measure the activities of the euglobulins, they were dissolved in a known volume of physiological saline, but varying amounts of precipitate remained insoluble as fine suspensions.) The highest recoveries of units were achieved by dialysing either of the water-diluted sera (2- or

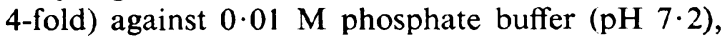
although almost as good yields were obtained by dialysis against distilled water. With the latter 
COMPARISON OF VARIOUS METHO玄S

\begin{tabular}{|c|c|c|c|c|c|c|}
\hline \multirow[b]{2}{*}{ Run } & \multirow[b]{2}{*}{ Nos. } & \multirow[b]{2}{*}{ Fraction } & \multirow[b]{2}{*}{ Method of Preparing Euglobulin } & \multirow[b]{2}{*}{$\begin{array}{c}\text { Protein } \\
\text { Precipitated } \\
\text { (mg.) }\end{array}$} & \multicolumn{2}{|c|}{ Recovery } \\
\hline & & & & & $\begin{array}{l}\text { Per cent. } \\
\text { Total } \\
\text { Protein }\end{array}$ & $\begin{array}{l}\text { Per cent. } \\
\text { Total Lnits- } \\
\text { Precipitated }\end{array}$ \\
\hline \multirow{2}{*}{\multicolumn{2}{|c|}{1}} & I & $80 \mathrm{ml}$. serum against 2 litres for $48 \mathrm{hrs}$ & 99 & $3 \cdot 2$ & 40 \\
\hline & & III & $\begin{array}{l}\text { Supernatant of } 1) \\
\text { Supernatant of } 11\}\end{array}$ & 20 & $0 \cdot 7$ & 10 \\
\hline & 2 & I & $\begin{array}{l}45 \mathrm{ml} \text { serum } \\
(\mathrm{pH} \text { adjusted to } \mathrm{pH} 8 \text { with } 0.01 \mathrm{M} \text { phosphate buffer) }\end{array}$ & 145 & $4 \cdot 2$ & 34 \\
\hline & 3 & I & $\begin{array}{l}25 \mathrm{ml} \text {. serum } \\
\text { Redialysed against } 2 \text { litres for } 48 \text { hrs }\end{array}$ & 86 & $18 \cdot 5$ & 25 \\
\hline \multirow{3}{*}{\multicolumn{2}{|c|}{$4 A$}} & $\begin{array}{l}\text { J } \\
\text { la }\end{array}$ & $\begin{array}{l}20 \mathrm{ml} \text {. serum diluted } \times 12 \text { with tap water } \\
\text { Distilled water washings of above }\end{array}$ & 118 & $7 \cdot 9$ & 75 \\
\hline & & Ib & Washed precipitate in 0.85 saline & 63 & $4 \cdot 7$ & 25 \\
\hline & & $\mathrm{Ia}+\mathrm{Ib}$ & $\mathrm{Ia}+\mathrm{Ib}$ redialysed & 106 & $7 \cdot 1$ & 29 \\
\hline \multirow{5}{*}{\multicolumn{2}{|c|}{ 4B }} & I & $\begin{array}{l}\text { Stepwise dialysis } \\
20 \mathrm{ml} \text {. serum against tap water stirring }\end{array}$ & 81 & $5 \cdot 4$ & 150 \\
\hline & & II & Supernatant of I & 25 & $1 \cdot 7$ & $3 \cdot 8$ \\
\hline & & III & Supernatant of II & 41 & $2 \cdot 7$ & $1 \cdot 0$ \\
\hline & & IV & Supernatant of III & 35 & $2 \cdot 3$ & $3 \cdot 8$ \\
\hline & & & Precipitates $\mathrm{I}+\mathrm{II}$ in 0.85 saline redialysed & 88 & $5 \cdot 9$ & $3 \cdot 7$ \\
\hline \multirow{2}{*}{\multicolumn{2}{|c|}{5}} & I & $100 \mathrm{ml}$. serum against 5 litres tap water for $29 \mathrm{hrs}$ stirring & 325 & $2 \cdot 9$ & 3 \\
\hline & & II & Supernatant I against running tap water for $20 \mathrm{hrs}$ & 130 & $1 \cdot 2$ & 5 \\
\hline & $9 \mathrm{~A}$ & & $\begin{array}{l}96 \mathrm{ml} \text {. serum } \cdots 1,400 \mathrm{ml} \text {. deionized water at } 4^{\circ} \mathrm{C} \text {. Centri- } \\
\text { fuged at } 4,000 \text { r.p.m. and } 4^{\circ} \mathrm{C} \text {. for } 15 \mathrm{~min} \text {. }\end{array}$ & 482 & $5 \cdot 75$ & 70 은 \\
\hline & 10 & & $100 \mathrm{ml}$. serum as above & 450 & $5 \cdot 1$ & $44 \cdot \frac{4}{7}$ \\
\hline & 2 & II & \multirow{2}{*}{$\begin{array}{l}\text { Slow addition of saturated ammonium sulphate till solu- } \\
\text { tion } 33 \text { per cent. Saturated }\end{array}$} & 642 & $19 \cdot 5$ & 31 \\
\hline & 5 & III & & 414 & $3 \cdot 7$ & $8 \cdot 2$ \\
\hline
\end{tabular}

* See p. 370 .

method, however, there was generally more euglobulin precipitated and so the increases in specific activity were not as great. The efficiency of euglobulin precipitation was much greater with Serum $B$ than with Serum A, as shown by the greater increase in specific activity. (Averaging the results of Experiments a, b, d, and e with each serum, the concentration achieved was three times greater with $\mathrm{B}$ than with A.) Dialysis against 0.05 M phosphate, physiological saline, and Ringer's solution invariably resulted in a considerable loss of units, confirming previous experiments. The specific activities of the euglobulins fell rapidly if the dialysis was continued for longer than $48 \mathrm{hrs}$.

\section{Ion-exchange Chromatography}

Analysis of the fractions obtained by DEAE cellulose chromatography of normal human serum (Stanworth, 1959) has indicated that 19S $\gamma$ globulin can be readily separated from the major portion of the 7S $\gamma$ globulin and from the 19S $\alpha_{2}$ glycoprotein. This technique would therefore appear to be an ideal successive step to the initial euglobulin precipitation from rheumatoid serum, as it offers a means of freeing the rheumatoid factor from the co-precipitated 7S $\gamma$ globulin. Such an approach in Fractionations 1, 2, 3, and 5B has provided the results given in Table $\mathrm{V}$. 
III

\section{OF PRECIPITATING EUGLOBULIN}

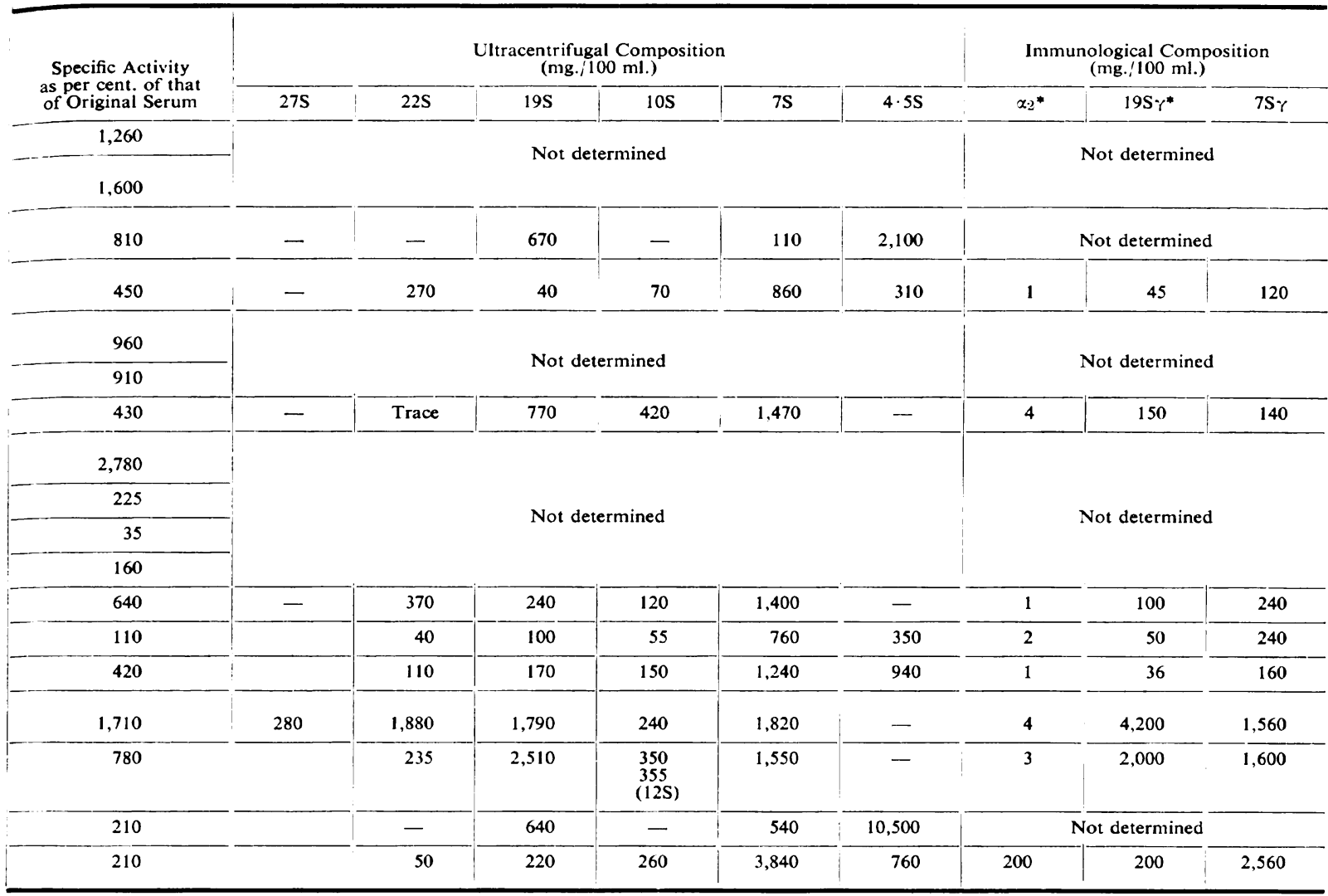

water for $24 \mathrm{hrs}$ at $4^{\circ} \mathrm{C}$. without stirring, except where stated.

Alternatively, DEAE cellulose chromatography would be useful in freeing rheumatoid factor from the bulk of $19 \mathrm{~S} \alpha_{2}$ glycoprotein sedimented with it in zone-centrifugation procedures.

As will be observed from Table $\mathrm{V}$, however, a disadvantage of the chromatographic procedure is the relatively poor yield of Rose-Waaler activity (always less than 50 per cent.) recovered from DEAE cellulose columns. This can probably be ascribed to the low recoveries of protein, particularly the macroglobulin. In this connexion, the batch chromatographic procedure (described later) was found to be more useful. As far as purification of rheumatoid factor is concerned, the column chromatographic procedure was found to increase the ratio of $19 \mathrm{~S}$ to $7 \mathrm{~S} \gamma$ globulin, as shown in the results of Fractionation 5 (Table V), although $7 \mathrm{~S} \gamma$ globulin was not completely removed.

As would be expected from the analysis of normal serum chromatographic fractions, DEAE cellulose chromatography proved incapable of freeing euglobulin precipitates from contaminating $4 \cdot 5 \mathrm{~S}$ components (Table V).

\section{Concentration of Chromatographic Fractions}

In ascribing loss of activity to the column chromatographic treatment, it is important to consider the contribution made by the subsequent 
EFFICIENCY OF SEPARATION OF RHEUMATOID FACTOR Bঙ.

\begin{tabular}{|c|c|c|c|c|c|c|c|c|c|}
\hline \multirow[b]{3}{*}{ Material } & \multirow[b]{3}{*}{$\begin{array}{c}\text { Volume } \\
\text { (ml.) }\end{array}$} & \multirow[b]{3}{*}{ Method } & \multirow[b]{3}{*}{ Dilution } & \multicolumn{6}{|c|}{ Supernatant } \\
\hline & & & & 1 & 2 & $1 \times 2$ & & 3 & $1 \times 3$ \\
\hline & & & & $\begin{array}{c}\text { Volume } \\
\text { (ml.) }\end{array}$ & 1/Titre & $\begin{array}{l}\text { Total Units } \\
\text { of Activity } \\
\text { Recovered }\end{array}$ & $\begin{array}{l}\text { Per cent. } \\
\text { of Units } \\
\text { Recovered }\end{array}$ & $\begin{array}{c}\text { Protein } \\
\text { Concen- } \\
\text { tration } \\
(\mathbf{m g} / \mathrm{ml} \text {.) }\end{array}$ & $\begin{array}{l}\text { Total } \\
\text { Protein } \\
\text { (mg.) }\end{array}$ \\
\hline $\begin{array}{l}\text { "A" } \\
\text { (a) } \\
\text { (b) } \\
\text { (c) } \\
\text { (d) } \\
\text { (c) } \\
\text { (f) } \\
\text { (g) } \\
\text { (h) }\end{array}$ & $\begin{array}{l}2 \\
2 \\
2 \\
2 \\
2 \\
2 \\
2 \\
2 \\
2\end{array}$ & $\begin{array}{l}\text { Neat serum } \\
\times 2 \text { dilution dialyse } \mathrm{H}_{2} \mathrm{O} \\
\times 2 \text { dilution dialyse } 0 \cdot 01 \mathrm{M} \\
\times 2 \text { dilution dialyse } 0 \cdot 05 \mathrm{M} \\
\times 4 \text { dilution dialyse } \mathrm{H}_{2} \mathrm{O} \\
\times 4 \text { dilution dialyse } 0 \cdot 01 \mathrm{M} \\
\times 4 \text { dilution dialyse } 0 \cdot 05 \mathrm{M} \\
\text { Dialyse against } \mathrm{N} \text {. } \mathrm{NaCl} \\
\text { Dialyse against Ringer's solution }\end{array}$ & $\begin{array}{l}\overline{1 / 16} \\
1 / 16 \\
1 / 16 \\
1 / 18 \\
1 / 18 \\
1 / 18 \\
1 / 15 \\
1 / 15\end{array}$ & $\begin{array}{l}2 \\
4 \\
4 \\
4 \\
8 \\
8 \\
8 \\
2 \cdot 4 \\
2 \cdot 3\end{array}$ & $\begin{array}{r}512 \\
52 \\
32 \\
64 \\
4 \\
32 \\
64 \\
256 \\
256\end{array}$ & $\begin{array}{r}1,024 \\
128 \\
128 \\
256 \\
32 \\
256 \\
512 \\
614 \\
588\end{array}$ & $\begin{array}{l}100 \\
12 \cdot 5 \\
12 \cdot 5 \\
25 \\
3 \cdot 2 \\
25 \\
50 \\
60 \\
57\end{array}$ & $\begin{array}{l}97 \\
34 \\
40 \\
35 \\
21 \\
26 \\
20 \\
69 \\
72\end{array}$ & $\begin{array}{l}194 \\
136 \\
160 \\
140 \\
168 \\
208 \\
160 \\
165 \\
163\end{array}$ \\
\hline $\begin{array}{l}\text { "B" } \\
\text { (a) } \\
\text { (b) } \\
\text { (c) } \\
\text { (d) } \\
\text { (f) } \\
\text { (g) } \\
\text { (h) }\end{array}$ & $\begin{array}{l}2 \\
2 \\
2 \\
2 \\
2 \\
2 \\
2 \\
2 \\
2\end{array}$ & $\begin{array}{l}\text { Neat serum } \\
\times 2 \text { dilution dialyse } \mathrm{H}_{2} \mathrm{O} \\
\times 2 \text { dilution dialyse } 0.01 \mathrm{M} \\
\times 2 \text { dilution dialyse } 0.05 \mathrm{M} \\
\times 4 \text { dilution dialyse } \mathrm{H}_{2} \mathrm{O} \\
\times 4 \text { dilution dialyse } 0.01 \mathrm{M} \\
\times 4 \text { dilution dialyse } 0.05 \mathrm{M} \\
\text { Dialyse against } \mathrm{N} \text {. } \mathrm{NaCl} \\
\text { Dialyse against } \mathrm{Ringer's} \mathrm{solution}\end{array}$ & $\begin{array}{l}1 / 16 \\
1 / 16 \\
1 / 16 \\
1 / 18 \\
1 / 18 \\
1 / 18 \\
1 / 15 \\
1 / 15\end{array}$ & $\begin{array}{l}2 \\
4 \\
4 \\
4 \\
8 \cdot 5 \\
9 \\
8 \cdot 5 \\
2 \cdot 4 \\
2 \cdot 4\end{array}$ & $\begin{array}{r}512 \\
64 \\
32 \\
256 \\
32 \\
16 \\
256 \\
512 \\
256\end{array}$ & $\begin{array}{r}1,024 \\
256 \\
128 \\
1,024 \\
272 \\
144 \\
2,180 \\
1,230 \\
615\end{array}$ & $\begin{array}{c}100 \\
25 \\
12 \cdot 5 \\
100 \\
27 \\
14 \\
213 \\
120 \\
60\end{array}$ & $\begin{array}{l}87 \\
39 \\
32 \\
32 \\
19 \\
17 \\
23 \\
72 \\
75\end{array}$ & $\begin{array}{l}174 \\
156 \\
128 \\
128 \\
162 \\
153 \\
195 \\
170 \\
180\end{array}$ \\
\hline
\end{tabular}

ACTIVITIES AND COMPOSITIONS OF RHEUMATOID FACTO

\begin{tabular}{|c|c|c|c|c|c|c|c|}
\hline Run & Sample & $\begin{array}{c}\text { Protein } \\
\text { Applied } \\
\text { (mg.) }\end{array}$ & $\begin{array}{l}\text { Protein } \\
\text { Recovered } \\
\text { (mg.) }\end{array}$ & $\begin{array}{c}\text { Per cent. } \\
\text { Protein } \\
\text { Recovered }\end{array}$ & $\begin{array}{c}\text { Units } \\
\text { Applied }\end{array}$ & $\begin{array}{c}\text { Total } \\
\text { Units } \\
\text { Recovered }\end{array}$ & $\begin{array}{l}\text { Per cent. } \\
\text { of Units } \\
\text { Recovered }\end{array}$ \\
\hline 1 & Euglobulin & 78 & 39 & 50 & 1,720 & 330 & 19 \\
\hline \multirow[t]{2}{*}{2} & Euglobulin I & 115 & 46 & 40 & 8,800 & 1,230 & 14 \\
\hline & Euglobulin II & 220 & 40 & 18 & 8,800 & 360 & 4 \\
\hline \multirow{2}{*}{3} & \multirow{2}{*}{ Euglobulin } & \multirow{2}{*}{81} & \multirow{2}{*}{ - } & \multirow{2}{*}{ - } & \multirow{2}{*}{38,000} & 2,200 & \multirow{2}{*}{46} \\
\hline & & & & & & 15,360 & \\
\hline 5 & Euglobulin II + III & 395 & 239 & 60 & 24,350 & 8,100 & 33 \\
\hline 6 & Zone Centrifuge Fraction & 47 & - & - & 17,900 & 1,022 & 6 \\
\hline \multirow[t]{2}{*}{ 7A } & Serum & 765 & 700 & 91 & 25,600 & 21.282 & 83 \\
\hline & Cohn Fraction I of Batched Serum & 90 & 123 & 137 & 7,680 & 1,540 & 20 \\
\hline 7B & Cohn Fraction I of Serum & 35 & 38 & 109 & 15,360 & 3,580 & 23 \\
\hline 8 & Serum & 6,900 & 6,700 & 97 & 97,000 & 51,100 & 53 \\
\hline Roma & res (e.g. I and II) denote difierent ch & ographic f & ns. & - See $\mathrm{r}$ & & "Ac & Fraction" \\
\hline
\end{tabular}


$N$

VARIOUS METHODS OF EUGLOBULIN PRECIPITATION

\begin{tabular}{|c|c|c|c|c|c|c|c|c|c|c|}
\hline & & & \multicolumn{8}{|c|}{ Precipitate (in $2 \mathrm{ml}$. saline) } \\
\hline & $\mathbf{t}=\mathbf{S}$ & & 4 & & & 5 & & & $4 / 5$ & \\
\hline $\begin{array}{l}\text { Per cent. } \\
\text { Protein } \\
\text { Recovered }\end{array}$ & $\begin{array}{l}\text { Specific } \\
\text { Activity }\end{array}$ & $\begin{array}{c}\text { Specific } \\
\text { Activity as } \\
\text { per cent. } \\
\text { of that of } \\
\text { Initial Serum }\end{array}$ & 1/Titre & $\begin{array}{l}\text { Total Units } \\
\text { of Activity } \\
\text { Recovered }\end{array}$ & $\begin{array}{l}\text { Per cent. } \\
\text { of Units } \\
\text { Recovered }\end{array}$ & $\begin{array}{c}\text { Protein } \\
\text { Concen- } \\
\text { tration } \\
(\mathbf{m g} \cdot / 100 \mathrm{ml} .)\end{array}$ & $\begin{array}{l}\text { Total } \\
\text { Protein } \\
\text { (mg.) }\end{array}$ & $\begin{array}{l}\text { Per cent. } \\
\text { Protein } \\
\text { Recovered }\end{array}$ & $\begin{array}{l}\text { Specific } \\
\text { Activity }\end{array}$ & $\begin{array}{l}\text { Specific } \\
\text { Activity as } \\
\text { per cent. } \\
\text { of that of } \\
\text { Initial Serum }\end{array}$ \\
\hline $\begin{array}{r}100 \\
70 \\
83 \\
72 \\
87 \\
108 \\
83 \\
85 \\
84\end{array}$ & $\begin{array}{l}5 \cdot 3 \\
0 \cdot 9 \\
0 \cdot 8 \\
1 \cdot 8 \\
0 \cdot 2 \\
1 \cdot 2 \\
3 \cdot 3 \\
3 \cdot 7 \\
3 \cdot 6\end{array}$ & $\begin{array}{r}100 \\
17 \\
16 \\
34 \\
4 \\
23 \\
60 \\
70 \\
68\end{array}$ & $\begin{array}{r}128 \\
64 \\
8 \\
128 \\
128 \\
8 \\
4 \\
4\end{array}$ & $\begin{array}{r}256 \\
128 \\
16 \\
256 \\
256 \\
16 \\
8 \\
8\end{array}$ & $\begin{array}{l}25 \\
12.5 \\
1.5 \\
25 \\
25 \\
1 \cdot 5 \\
0.8 \\
0.8\end{array}$ & $\begin{array}{l}4 \\
2 \\
1 \cdot 2 \\
2 \cdot 8 \\
2 \cdot 6 \\
1 \cdot 6 \\
\overrightarrow{2 \cdot 0}\end{array}$ & $\begin{array}{l}8 \\
4 \\
2 \cdot 4 \\
5 \cdot 6 \\
5 \cdot 2 \\
3 \cdot 2 \\
\overline{4 \cdot 0}\end{array}$ & $\begin{array}{l}4 \cdot 1 \\
2 \cdot 0 \\
1 \cdot 2 \\
2 \cdot 9 \\
2 \cdot 7 \\
1 \cdot 6 \\
2 \cdot-0\end{array}$ & $\begin{array}{l}32 \\
32 \\
6 \cdot 6 \\
48 \cdot 5 \\
49 \cdot 1 \\
\frac{5}{2}\end{array}$ & $\begin{array}{c}600 \\
600 \\
120 \\
920 \\
930 \\
94 \\
\frac{38}{38}\end{array}$ \\
\hline $\begin{array}{r}100 \\
90 \\
73 \\
73 \\
93 \\
88 \\
112 \\
98 \\
103\end{array}$ & $\begin{array}{r}5 \cdot 9 \\
1.6 \\
1.0 \\
8 \cdot 0 \\
1 \cdot 7 \\
0.9 \\
11 \cdot 2 \\
7.1 \\
3 \cdot 4\end{array}$ & $\begin{array}{r}100 \\
27 \\
17 \\
140 \\
29 \\
16 \\
190 \\
120 \\
58\end{array}$ & $\begin{array}{r}256 \\
512 \\
8 \\
512 \\
512 \\
8 \\
4 \\
4\end{array}$ & $\begin{array}{r}512 \\
1,024 \\
16 \\
1,024 \\
1,024 \\
16 \\
8 \\
8\end{array}$ & $\begin{array}{c}50 \\
100 \\
1 \cdot 5 \\
100 \\
100 \\
1 \cdot 5 \\
0 \cdot 8 \\
0.8\end{array}$ & $\begin{array}{l}3 \cdot 7 \\
2 \cdot 5 \\
2 \cdot 0 \\
3 \cdot 5 \\
2.6 \\
0.6 \\
0.7 \\
0.4\end{array}$ & $\begin{array}{l}7 \cdot 4 \\
5 \cdot 0 \\
4 \cdot 0 \\
7 \cdot 0 \\
5 \cdot 2 \\
1 \cdot 2 \\
1 \cdot 4 \\
0 \cdot 8\end{array}$ & $\begin{array}{l}4 \cdot 3 \\
2 \cdot 9 \\
2 \cdot 3 \\
4 \cdot 0 \\
3 \cdot 0 \\
0 \cdot 7 \\
0 \cdot 8 \\
0 \cdot 5\end{array}$ & $\begin{array}{c}67 \cdot 5 \\
204 \\
4 \\
146 \\
197 \\
13 \cdot 2 \\
5 \cdot 7 \\
10\end{array}$ & $\begin{array}{r}1,150 \\
3,460 \\
88 \\
2,500 \\
3,340 \\
200 \\
97 \\
170\end{array}$ \\
\hline
\end{tabular}

PREPARATIONS OBTAINED BY DEAE CELLULOSE CHROMATOGRAPHY

\begin{tabular}{|c|c|c|c|c|c|c|c|c|c|c|}
\hline \multicolumn{3}{|c|}{ "Active" Fraction } & \multicolumn{8}{|c|}{ Composition of "Active" Fraction (mg./100 ml.) } \\
\hline \multirow{2}{*}{ Units } & \multirow{2}{*}{$\begin{array}{l}\text { Specific } \\
\text { Activity }\end{array}$} & \multirow{2}{*}{$\begin{array}{l}\text { Specific Activity } \\
\text { as percentage of } \\
\text { that of Material } \\
\text { Applied }\end{array}$} & \multicolumn{5}{|c|}{ Ultracentrifugal } & \multicolumn{3}{|c|}{ Immunological } \\
\hline & & & $22 S$ & $19 \mathrm{~S}$ & $10 S$ & $7 \mathrm{~S}$ & $4 \cdot 5 S$ & $\alpha_{2} *$ & $19 S \gamma^{*}$ & $7 S_{\gamma}$ \\
\hline 320 & 50 & 230 & - & 20 & - & 90 & 210 & \multicolumn{3}{|c|}{ Not determined } \\
\hline 1,200 & 150 & 200 & - & 150 & - & 25 & 470 & \multirow{2}{*}{\multicolumn{3}{|c|}{ Not determined }} \\
\hline 210 & $7 \cdot 8$ & 40 & - & 170 & - & 60 & 1,090 & & & \\
\hline 2,200 & 116 & 20 & 80 & 130 & 70 & 210 & 350 & 6 & 100 & 30 \\
\hline 15,360 & 2,110 & 430 & - & 210 & - & - & 550 & \multicolumn{3}{|c|}{ Not determined } \\
\hline 2,560 & 128 & 210 & 40 & 180 & - & 280 & - & 3 & 45 & 20 \\
\hline 2,560 & 140 & 230 & 30 & 170 & - & 260 & - & 12 & 35 & 25 \\
\hline II $\quad 1,022$ & $\left.\begin{array}{l}52 \\
69\end{array}\right\}$ & 20 & - & 330 & - & 90 & 190 & 5 & 10 & 5 \\
\hline 15,000 & 59 & 180 & \multicolumn{5}{|c|}{ Not determined } & & & \\
\hline $\begin{array}{c}900 \\
\text { After concentration } \\
170\end{array}$ & 110 & 60 & - & 250 & 30 & 80 & - & 1 & 18 & 40 \\
\hline $\begin{array}{c}2,400 \\
\text { After concentration } \\
380\end{array}$ & 105 & 120 & - & 35 & 50 & 170 & - & 3 & 50 & 60 \\
\hline 34,700 & 64 & 460 & - & 45 & 20 & 65 & 370 & 3 & 50 & 40 \\
\hline
\end{tabular}

Chromatographic fraction containing majority of serological activity. 


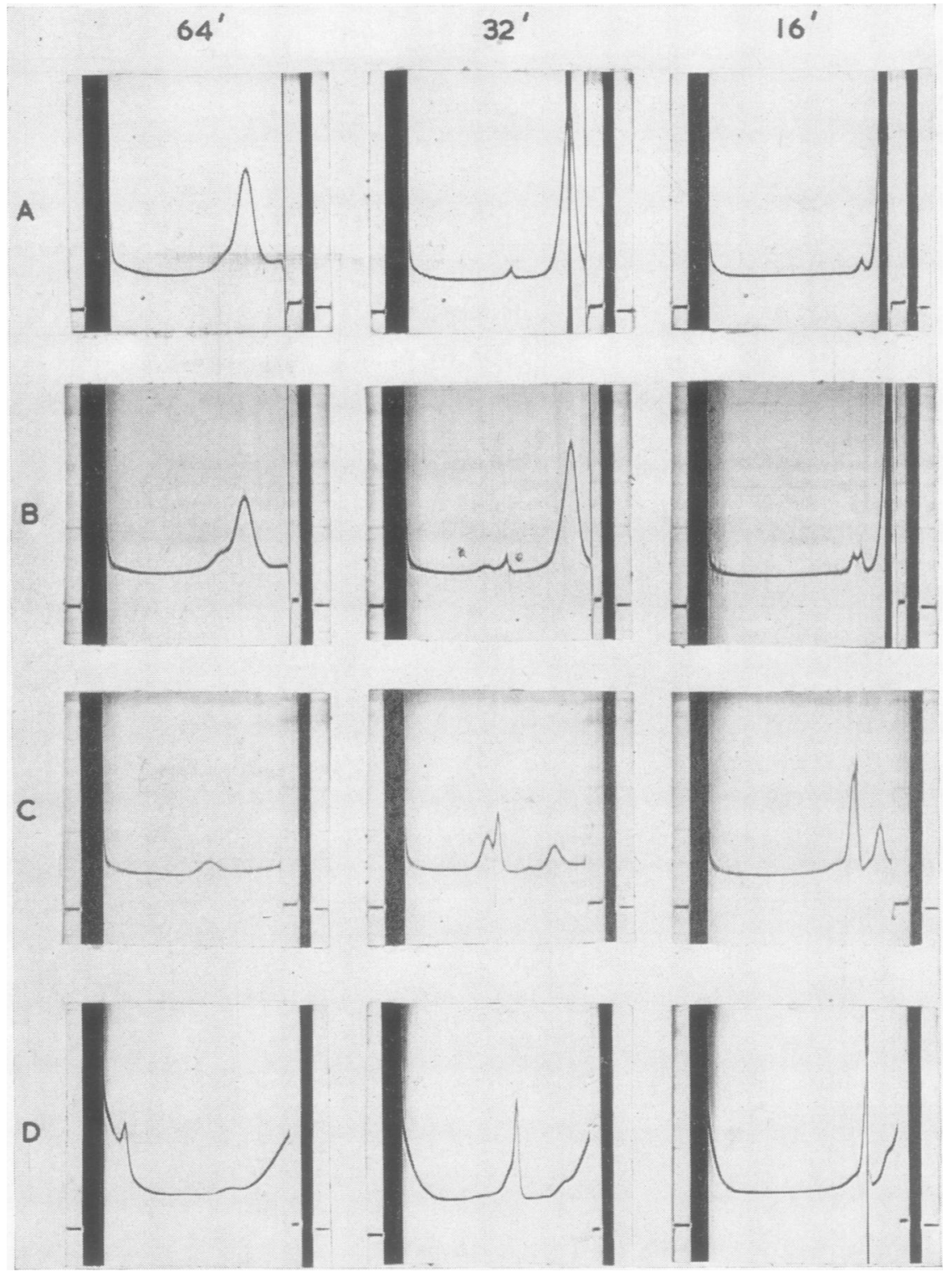

Fig. 1(A).-Normal serum (diluted 1:5).

Fig. 1(B).-Rheumatoid serum (No. 9, patient F.A., diluted $1: 5$ ).

Fig. 1(C).-Euglobin preparation from (B) above (diluted $1: 5$ ).

Fig. 1(D).-Zone centrifugation, high molecular weight fraction from above.

Solvent: phosphate buffer pH 6.9; $\mathrm{M}=0.06+0.15 \mathrm{M} \mathrm{NaCl}$.

Speed: 60,000 r.p.m.; temperature $20^{\circ} \mathrm{C}$.

Note presence of abnormally large amounts of $19 S$ and $22 S$ fractions in (B) and the progressive concentration and purification of the high molecular weight components in (C) and (D). 


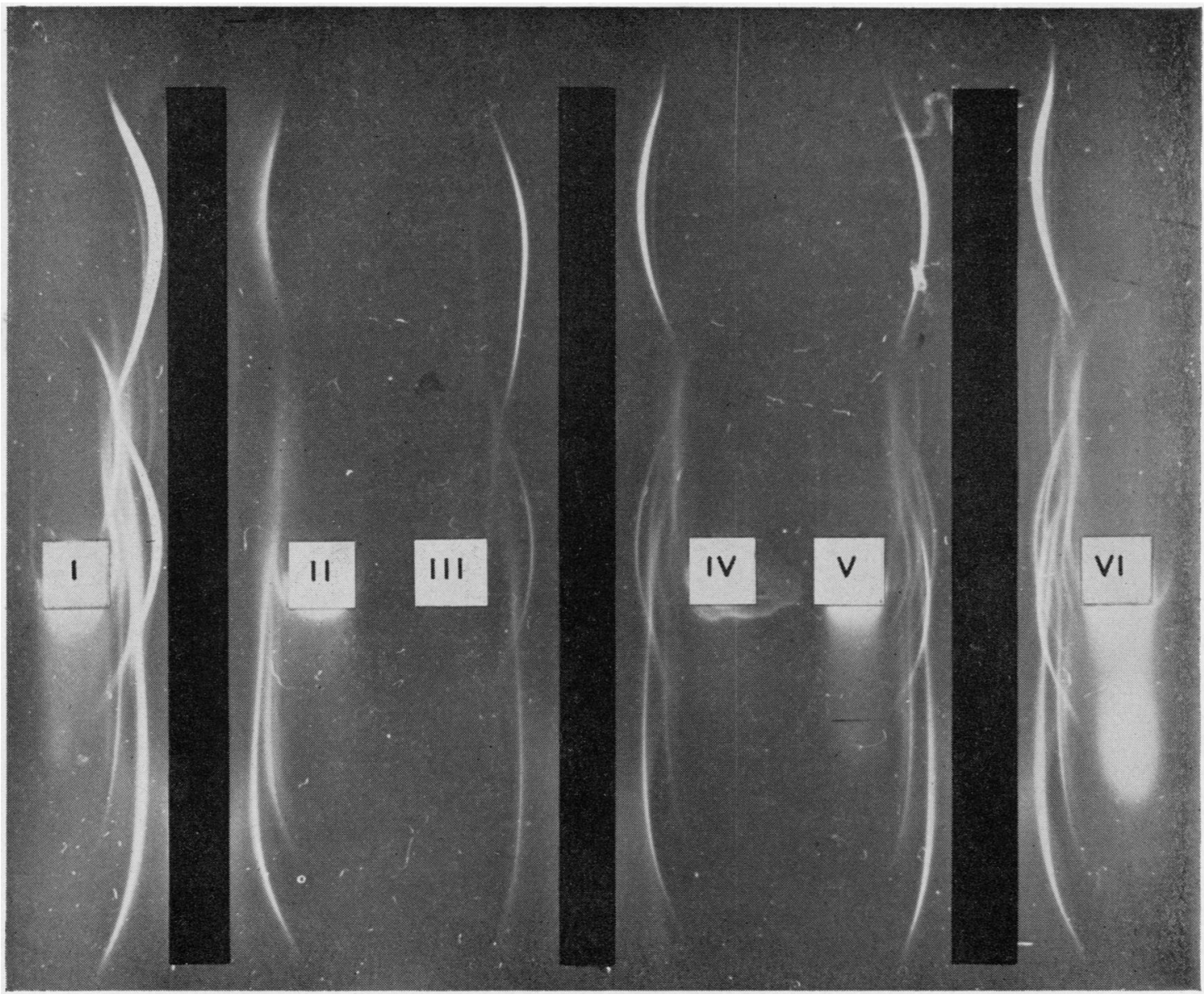

Fig. 2(I).-Rheumatoid serum (No. 9).

Fig. 2(II).--Euglobulin precipitate from (I) above prepared by dilution with de-ionized water $(1: 15)$.

Fig. 2(III).-Supernatant from (II).

Fig. 2(IV), (V), (VI).-Successive harvestings of euglobulin precipitates after dialysis of rheumatoid serum No. 9 against de-ionized water (15 volumes) with slow stirring for 2,5 , and 23 hrs respectively. Immuno-electrophoresis performed in 0.8 per cent. agar in barbitone buffer $(\mathrm{pH} 8.6 ; \mathrm{I}=0.05)$. A current of $15 \mathrm{ma}$. was passed for $4 \mathrm{hrs}$.

Antiserum-anti normal human serum.

Note: In $\gamma$ globulin zone, $7 \mathrm{~S} \gamma$ globulin can be seen as a prolonged asymmetric line in all samples. 19S $\gamma$ globulin appears shorter between this and the cup in all samples except (III).

Euglobulin precipitate obtained by dilution (Sample II) consists mainly of $7 \mathrm{~S}$ and $19 \mathrm{~S} \gamma$ globulins with only small amounts of albumin and $\alpha_{2}$ globulin. Supernatant (Sample III) appears substantially free from 19S $\gamma$ globulin, at least in the dilution tested.

In contrast, euglobulins prepared by dialysis (Samples IV, V, and VI) are immuno-electrophoretically complex, and 19S $\gamma$ globulin occurs in all these precipitates. 
concentration of the dilute chromatographic fraction solutions. Various concentrating procedures have been adopted, none of which has proved entirely satisfactory.

For instance, as is shown in Table VI (opposite), losses of activity as high as 95 per cent. were recorded during concentration by negative pressure ultrafiltration through Visking dialysis tubing and by the carbowax (polyethylene glycol) technique described by Kohn (1959), whilst losses of 80 per cent. occurred during ultrafiltration through collodion thimbles accompanied by simultaneous dialysis against buffered saline. Recoveries by ultrafiltration through Visking tubing were improved by massaging adherent protein off the walls of the tubing before pouring off the liquid.

These results, which are similar to those reported by Stanworth (1959) in a study of the effect of various concentration procedures on horse dandruff reagin, suggest that rheumatoid factor is highly susceptible to surface denaturation when purified.

An ultracentrifugal technique employed recently in the concentration of urinary colloid (Rowe and Soothill, 1961) would appear to offer improvements over the procedures just described, all of which involve the rheumatoid factor coming into contact with relatively large surface areas. A modification of this procedure, to avoid pellet formation in the bottom of the tube by using a bottom layer comprised of an inert non-water-miscible solvent (Stanworth and others, 1961), would appear to be advantageous.

In some instances, precipitation of rheumatoid factor from solution by dialysis against water proved a useful concentration procedure, but this was often vitiated by the disadvantage that the products were nearly always redissolved only with difficulty and accompanying denaturation. In order to overcome these difficulties in Runs 8 and 9, techniques were adopted which avoided the need for subsequent concentration.

\section{Zone Centrifugation}

Of all the fractionation procedures employed, zone centrifugation is undoubtedly the mildest as far as recovery of Rose-Waaler activity is concerned. This is indicated by the results given in Table VII, where it will be seen that 100 per cent. recoveries of activity are often achieved.

ACTIVITIES AND COMPOSITIONS OF "RHEUMATOID FACTOR "ृ

\begin{tabular}{|c|c|c|c|c|c|c|c|}
\hline Run & Sample & $\begin{array}{c}\text { Units } \\
\text { Added }\end{array}$ & $\begin{array}{l}\text { Specific } \\
\text { Activity }\end{array}$ & $\begin{array}{l}\text { Units } \\
\text { Recovered }\end{array}$ & $\begin{array}{l}\text { Specific } \\
\text { Activity } \\
\text { (Bottom } \\
\text { of Tube) }\end{array}$ & $\begin{array}{l}\text { Per cent. } \\
\text { Units } \\
\text { Recovered }\end{array}$ & $\begin{array}{l}\text { Specific } \\
\text { Activity as } \\
\text { Percentage } \\
\text { of that of } \\
\text { Material } \\
\text { Applied }\end{array}$ \\
\hline \multirow[t]{3}{*}{1} & Serum & 64 & $1 \cdot 7$ & 112 & & 175 & \\
\hline & Euglobulin I & 128 & 22 & 128 & 28 & 100 & 130 \\
\hline & Euglobulin II & 512 & 29 & 353 & $42 \cdot 6$ & 69 & 150 \\
\hline \multirow[t]{2}{*}{3} & DEAE Chromatography Fraction $\dagger$ & 2,880 & 116 & 2,700 & $\begin{array}{c}\text { Top } \\
330 \\
\text { Bottom } \\
120\end{array}$ & 94 & $\begin{array}{l}280 \\
100\end{array}$ \\
\hline & Top of above & 1,920 & 330 & $\begin{array}{l}680 \\
\text { or } \\
1,280\end{array}$ & $\begin{array}{c}600 \\
\text { or } \\
1.200\end{array}$ & $\begin{array}{l}35 \\
\text { or } \\
70\end{array}$ & $\begin{array}{l}180 \\
\text { or } \\
360\end{array}$ \\
\hline \multirow{2}{*}{$\begin{array}{r}4 \mathrm{~A} \\
\mathbf{B}\end{array}$} & Euglobulin Ia $+\mathrm{Ib}$ & 2,300 & 29 & 1,000 & 580 & 44 & 200 \\
\hline & Euglobulin I + II & 2.900 & 44 & 8,200 & 190 & 280 & 430 \\
\hline $5+$ & Euglobulin I & 6,400 & 25 & 2,200 & 125 & 35 & 350 \\
\hline $6+$ & Serum & 115,000 & 63 & 61,900 & 380 & 54 & 600 \\
\hline $8 \ddagger$ & Cohn Fraction I of "Active" DEAE Batch Fraction & 6.550 & 65 & 2,050 & 77 & 31 & 120 \\
\hline \multirow{2}{*}{$\begin{array}{r}9 \mathrm{~A} \\
\mathrm{~B}\end{array}$} & \multirow[t]{2}{*}{ Euglobulin } & 655,000 & 1,710 & 615,750 & 5,120 & 94 & 300 \\
\hline & & - & - & 694,700 & 4,400 & - & - \\
\hline 10 & Euglobulin & 126,000 & 780 & 176,000 & 3,820 & 140 & 490 \\
\hline
\end{tabular}


TABLE VI

COMPARISON OF THE EFFICIENCY OF VARIOUS METHODS OF CONCENTRATING CHROMATOGRAPHIC FRACTIONS CONTAINING RHEUMATOID FACTOR

\begin{tabular}{|c|c|c|c|c|c|c|c|}
\hline Run & Fraction & Method of Concentration & $\begin{array}{c}\text { Concentration } \\
\text { Factor }\end{array}$ & $\begin{array}{l}\text { Units } \\
\text { Added }\end{array}$ & $\begin{array}{l}\text { Units } \\
\text { Recovered }\end{array}$ & $\begin{array}{l}\text { Per cent. } \\
\text { of Units } \\
\text { Recovered }\end{array}$ & $\begin{array}{l}\text { Per cent. } \\
\text { Protein } \\
\text { Recovered }\end{array}$ \\
\hline 1 & & $\begin{array}{l}\text { Ultrafiltration through Visking } \\
\text { tube (Grant, Rowe, and Stan- } \\
\text { worth, 1958) }\end{array}$ & 25 & 570 & 320 & 56 & Not determined \\
\hline 2 & I & $\begin{array}{l}\text { Ultrafiltration through Visking } \\
\text { tube (Grant, Rowe, and Stan- } \\
\text { worth, 1958) }\end{array}$ & 100 & 2,500 & 1,300 & 52 & Not determined \\
\hline 3 & II & Polyethylene glycol (Kohn, 1959) & 3 & 7,600 & 380 & 5 & 50 \\
\hline 5 & & $\begin{array}{l}\text { Ultrafiltration through collodion } \\
\text { thimbles with simultaneous } \\
\text { dialysis }\end{array}$ & 1 & 1,300 & 310 & 24 & Not determined \\
\hline 6 & I & $\begin{array}{l}\text { Ultrafiltration through collodion } \\
\text { thimbles with simultaneous } \\
\text { dialysis } \\
\text { Ultrafiltration through Visking } \\
\text { tube with simultaneous dialysis }\end{array}$ & 14 & 20,000 & 1,000 & 5 & Not determined \\
\hline $\begin{array}{r}\mathbf{7 A} \\
\mathbf{B}\end{array}$ & & As Run 5 & $\begin{array}{l}7 \\
7\end{array}$ & $\begin{array}{r}2,400 \\
900\end{array}$ & $\begin{array}{l}380 \\
170\end{array}$ & $\begin{array}{l}16 \\
19\end{array}$ & Not determined \\
\hline
\end{tabular}

Note: Above fractions are final products.

PREPARATIONS OBTAINED BY ZONE CENTRIFUGATION

\begin{tabular}{|c|c|c|c|c|c|c|c|c|c|c|c|c|c|c|c|c|c|}
\hline \multicolumn{12}{|c|}{$\begin{array}{c}\text { Ultracentrifugal Composition } \\
\text { (mg./100 ml.) }\end{array}$} & \multicolumn{6}{|c|}{$\begin{array}{l}\text { Immunological Composition } \\
\text { (mg. } / 100 \mathrm{ml} .)\end{array}$} \\
\hline \multicolumn{6}{|c|}{ Initial } & \multicolumn{6}{|c|}{ Final } & \multicolumn{3}{|c|}{ Initial } & \multicolumn{3}{|c|}{ Final } \\
\hline $27 \mathrm{~S}$ & $22 S$ & $19 S$ & $10 S$ & $7 \mathrm{~S}$ & $4 \cdot 5 S$ & $27 S$ & $22 S$ & $19 S$ & $10 S$ & $7 S$ & $4 \cdot 5 S$ & $\alpha_{2}$ & $19 \mathrm{~S} \gamma^{*}$ & $7 S_{\gamma}$ & $\alpha_{2} *$ & $19 S \gamma^{*}$ & $7 \mathrm{~S} \gamma$ \\
\hline & - & 130 & - & 840 & 2,730 & \multirow{2}{*}{\multicolumn{6}{|c|}{ Not determined }} & \multirow{2}{*}{\multicolumn{6}{|c|}{ Not determined }} \\
\hline & \multicolumn{5}{|c|}{ Not determined } & & & & & & & & & & & & \\
\hline & 130 & 170 & 100 & 280 & 420 & \multicolumn{6}{|c|}{ Not determined } & 6 & 100 & 3 & \multicolumn{3}{|c|}{ Not determined } \\
\hline \multicolumn{6}{|c|}{ Not determined } & - & - & 63 & - & - & - & \multicolumn{3}{|c|}{ Not determined } & 一 & 6 & $0 \cdot 1$ \\
\hline & Trace & 770 & 420 & 1,470 & 一 & 170 & 250 & 600 & 80 & 230 & - & 4 & 150 & 140 & 1 & 100 & 20 \\
\hline & 370 & 240 & 120 & 1,400 & 一 & 70 & 450 & 830 & 150 & 530 & - & 1 & 100 & 240 & - & 200 & 60 \\
\hline & 40 & 100 & 55 & 760 & 350 & 一 & 30 & 210 & - & 190 & - & 3 & 50 & 240 & 3 & 50 & 40 \\
\hline & - & 100 & - & 1,000 & 7,000 & -9 & 一 & 270 & 一 & 780 & 1,010 & 75 & 65 & 1,280 & 5 & 10 & 5 \\
\hline & 16 & 160 & 130 & 190 & - & - & - & 104 & - & - & - & 1 & 200 & 20 & 1 & 50 & 5 \\
\hline 280 & 1,880 & 1,790 & 240 & 1,820 & - & 115 & 210 & 595 & 30 & 50 & - & 4 & 4,200 & 1,560 & 4 & 600 & 280 \\
\hline & & & & & & 190 & 910 & 930 & 120 & 340 & - & & & & 0 & 1,600 & 840 \\
\hline & 235 & 2,510 & $\begin{array}{c}355 \\
350 \\
(12 S)\end{array}$ & 1,550 & - & & 15 & 795 & 25 & 85 & - & $<3$ & 2,000 & 1,600 & $<3$ & 700 & 240 \\
\hline
\end{tabular}

out in 40 angle head rotor at 36,000 r.p.m. 
Zone centrifugation was usually used as a final step in the removal of low molecular weight (7S) $\gamma$ globulin contaminant from rheumatoid factor, the other 19S component (i.e. $\alpha_{2}$ glycoprotein) having been previously removed by euglobulin precipitation and DEAE cellulose chromatography. Adoption of zone centrifugation as a preliminary step, as in Fractionation 6, did not prove very satisfactory; a drawback with these large starting volumes is the necessity of using angle rotors in order to be able to process sufficiently large volumes of rheumatoid serum. This has led to the contamination of the $19 \mathrm{~S}$ zone with low molecular weight serum constituents (as shown in the results in Table VII).

\section{DEAE Cellulose Batch Chromatography}

With the aim of increasing the speed of the chromatographic procedure and improving yields, a batch process (Stanworth, 1960) was tried in the isolation of rheumatoid factor. As shown in Table $\mathrm{V}$, protein recoveries of the order of 90 per cent. were obtained when rheumatoid serum was fractionated initially in this way (as in Fractionations 7A and 8). Corresponding improved recoveries (53 to 83 per cent.) of Rose-Waaler activity were also recorded, although this might reflect to some extent the superiority of whole serum as starting material in preference to euglobulin (used in the column procedures in Fractionations 1, 2, 3, 5, and 6). In considering recoveries of both protein and rheumatoid activity, one must bear in mind that in the batch procedure the final eluent was $1.5 \mathrm{M} \mathrm{NaCl}$.

The batch chromatographic technique achieved similar resolution of serum proteins to that obtained by the column procedure, the eluate containing 19S $\gamma$ globulin being contaminated with $4.5 \mathrm{~S}$ component and also with relatively small amounts of 7S $\gamma$ globulin. Further purification was accomplished on these occasions by a subsequent Cohn low-temperature ethanol fractionation procedure, as modified by Dr. K. W. Walton. Rose-Waaler activity was found to be completely precipitated along with the $\gamma$ globulins, leaving behind in solution both $19 S \alpha_{2}$ glycoprotein and $4 \cdot 5 S$ albumin contaminants.

The poor recovery of activity in Fractionation 8, where the modified Cohn technique was employed as a second step after DEAE cellulose batch chromatography, was probably due to denaturation of either the rheumatoid factor or of traces of 7S $\gamma$ globulin, which may then inhibit the RoseWaaler tests (Franklin, 1960), brought about by the addition of relatively large volumes of $0 \cdot 1 \mathrm{M} \mathrm{NaOH}$ solution to adjust the $\mathrm{pH}$ to $7 \cdot 4$.

In Fractionation $7 \mathrm{~A}$, a repeat batch chromatographic procedure was made after Cohn fractionation, in an attempt to remove the remaining $7 \mathrm{~S} \gamma$ globulin. Unfortunately, however, although overall 100 per cent. recovery of protein was achieved, only a 20 per cent. recovery of Rose-Waaler activity was recorded (Table V).

For this reason, zone centrifugation was adopted as the final step in Run 8 , resulting in a 35 per cent. recovery of Rose-Waaler activity. This product contained only $19 \mathrm{~S}$ protein as revealed by ultracentrifugal analysis (see Table II), but immunological analysis revealed $5 \mathrm{mg} . / 100 \mathrm{ml}$. of $7 \mathrm{~S} \gamma$ globulin and traces of $\alpha_{2}$ glycoprotein.

\section{Discussion}

In this work on the isolation of rheumatoid factor, emphasis has been placed on the quantitative approach, often neglected in earlier studies. For instance, the enrichment of factor after each fractionation has been followed by measuring RoseWaaler activity and relating this to total protein concentration. On this basis, results have been expressed in terms of "specific activity". Attempts have also been made to determine the yields of active material from the arithmetical products of the specific activities of solutions with their volumes. It is readily admitted that individual quantitative assessments are somewhat approximate because of the inaccuracies inherent in the use of limiting dilution values as indices of Rose-Waaler activity. No other methods of assaying rheumatoid factor activity have been employed.

The ability to precipitate rheumatoid factor as euglobulin varied considerably from serum to serum. This may reflect the properties of the sera or critical differences in the methods of precipitation.

In Table IV, showing experiments performed under identical conditions with the different sera, this variability is clearly seen. It would thus appear that one of the major factors controlling the precipitation of rheumatoid factor by dialysis or dilution lies in the starting serum. Prolonged dialysis of serum results in the precipitation of large amounts of "inactive protein" (Table III, Run 4B), with a considerable drop in specific activity. This drop in specific activity, usually accompanied by an overall loss of units, is probably due to some form of denaturation of rheumatoid factor; it might also, however, be due in part to the production of aggregated 7S $\gamma$ globulin which is able to neutralize the rheumatoid factor by combining with it (Frank- 
lin, 1960), and to the precipitation of protein such as albumin which does not agglutinate sensitized sheep cells. Experience with Sera 5 and 9 would indicate that, with some sera at least, a waterdilution technique is more efficient than dialysis against water. Dilution will certainly have a more profound effect on interionic and intramolecular forces which in sera may tend to solubilize the rheumatoid factor. This technique also prevents the ionic strength from falling to zero level as obtained in complete dialysis and hence reduces the probability of denaturation.

Of the further procedures available for increasing the specific activity of rheumatoid factor preparations, chromatography on DEAE cellulose and zone ultracentrifugation have been most extensively employed. The efficiencies of such procedures may be classified in terms of yield of desired product, concentration of product without further manipulation, and discrimination between individual proteins. Rheumatoid euglobulin prepared by dilution or dialysis was desirable as starting material for zone ultracentrifugation, for it contained little 19S high molecular weight glycoprotein which would sediment with the rheumatoid factor.

In terms of discrimination, zone centrifugation can only be expected to separate proteins of the $19 S$ class and greater molecular weight from other serum proteins, and even this achievement requires special arrangements, such as suitable density gradients and minimum disturbance during the sampling of the tubes. In these experiments zone centrifugation did not achieve complete separation of $19 \mathrm{~S}$ protein from $7 \mathrm{~S}$ and $10 \mathrm{~S}$ material, but the majority of these proteins were removed. Re-centrifugation could have been adopted, but was avoided partly because repeated ultracentrifugation of rheumatoid factor had been shown to decrease its activity (Svartz and others, 1958) and also involved redialysis of the sample.

Column chromatography on DEAE cellulose enables the separation of rheumatoid factor from the bulk of the 7S $\gamma$ globulin precipitated as euglobulin, but complete separation was not achieved. Losses of protein and activity were always considerable. Products obtained by chromatographic techniques were usually contaminated with $7 \mathrm{~S} \gamma$ globulin, albumin if this was present in the euglobulin, traces of $\alpha_{2}$ high molecular weight glycoprotein, and $\beta$ lipoprotein, and contained large amounts of 19S $\gamma$ globulin. It is thus essential that this step be followed by zone ultracentrifugation to remove low molecular weight contaminants.

Batch chromatography achieved a separation similar to that obtained by the column technique, but total recovery of both protein and units was usually much better. The superiority of the batch chromatographic procedure over the column procedure, in addition to that of speed, may depend on the rheumatoid factor (and other proteins) being attached to the resin for a minimum period of time and so being less likely to be irreversibly denatured.

The lower losses of activity associated with the zone ultracentrifugation procedure could be attributed to the "milder" conditions experienced in this method, which avoids precipitation and adsorption on to resins with subsequent solubilization and elution-procedures which may produce denaturing of the molecule. The use of a sucrose density gradient may help to protect the rheumatoid molecule.

One possible index of denaturing available for the results of these studies lies in the appearance of additional ultracentrifugal components, e.g. 27S, $22 \mathrm{~S}$, and 10S. Four of the starting sera contained $22 \mathrm{~S}$ material, and three also contained $10 \mathrm{~S}$ protein. Whether or not these proteins were originally present in the sera or were produced on storage at $-20^{\circ} \mathrm{C}$. is not known, but Svartz (1960) believes that the rheumatoid factor is pre-existent in the blood as a globulin with a sedimentation coefficient of 18 to $19 \mathrm{~S}$.

The 10S component detected, particularly on euglobulin precipitation and Cohn fractionation, would appear to be produced during the experimental procedure. There is no evidence to suggest that this material resulted from the action of soluble $\gamma$ globulin aggregates in a manner analogous to the effect of adding soluble $\gamma$ globulin aggregates to normal human sera followed by incubation at $4^{\circ} \mathrm{C}$. (as described by Muller-Eberhard and Kunkel, 1960).

As purification proceeds, the rheumatoid factor becomes more susceptible to denaturing and therefore it is perhaps not justifiable to compare different fractionation procedures unless they were performed on the same starting material. Susceptibility to denaturing could be due to the removal of protective compounds, such as 7S $\gamma$ globulin which forms $22 \mathrm{~S}$ derivatives with 19S $\gamma$ globulin. Experiments performed by dialysing rheumatoid sera against 0.85 per cent. buffered saline and Ringer's solution, with little or no precipitation of euglobulin, results in the loss of a considerable amount of serological activity, suggesting the removal of dialysable activators which could include metal ions or compounds such as cysteine and ascorbic acid which may influence the surface groups of the molecule (e.g. sulphydryl groups). Decrease in activity 
could also be attributed to denaturing of the molecule itself or inhibition by aggregated 7S $\gamma$ globulin, but under the above conditions we should expect both of these effects to be at a minimum.

The special efforts that have been made to measure the amounts of individual proteins present in the solutions by immunological methods have served two purposes. In the first place, it has been useful as a guide to the specific discriminatory powers of special procedures, in particular, euglobulin precipitation. It was also hoped by means of this approach to obtain further information about the nature of the rheumatoid factor, in particular its relationship to $19 \mathrm{~S} \gamma$ globulin. In this context it is interesting to note that, while the estimation of $7 \mathrm{~S}$ component by analytical ultracentrifugation and 7S $\gamma$ globulin immunologically agreed reasonably well in most of the native sera, comparable analyses of preparations tended to show a considerable discrepancy explicable possibly in terms of the relative concentration of 7S components other than $\gamma$ globulin. Other possible explanations include the interaction of $19 \mathrm{~S}$ protein rheumatoid factor with $7 \mathrm{~S} \gamma$ globulin thus impeding diffusion of this protein through the agar plate.

Work performed to date has not shown whether or not rheumatoid factor is distinct from 19S $\gamma$ iso-agglutinins, or is a slightly altered $19 \mathrm{~S} \gamma$ globulin. Increases in serological activity have shown no evident parallel with 19S $\gamma$ concentrations as estimated immunologically. Attempts are now being made to see whether or not it is possible to resolve sheep cell agglutinating activity from iso-agglutinin activity.

Iso-agglutinin preparations from normal sera fail to give positive sheep cell agglutinating activity, although adsorbed by the sensitized sheep cell.

\section{Summary}

A detailed analysis has been made of methods previously used in attempts to isolate rheumatoid factor, including euglobulin precipitation, DEAE cellulose chromatography, zone centrifugation, and Cohn type low-temperature ethanol fractionation procedures.

The recovery of serological activity and increases in specific activity have been determined. The degree of resolution of the different techniques has been investigated by ultracentrifugal and immunological methods.

The most efficient way of preparing rheumatoid factor in a fairly pure state appears to be euglobulin precipitation by water dilution followed by zone centrifugation.

Methods involving euglobulin precipitation by prolonged dialysis against water or the addition of saturated ammonium sulphate, DEAE cellulose chromatography, and concentration procedures, such as ultrafiltration and carbowax (polyethylene glycol) techniques, were found to result in a considerable loss of serological activity.

With the techniques used to date it has not been possible to resolve rheumatoid factor and 19S $\gamma$ globulin.

The authors wish to thank Professor J. R. Squire for his advice and encouragement. Dr. J. F. Soothill kindly performed the quantitative precipitin estimations. We are also indebted to Dr. K. W. Walton for help with his modified Cohn fractionation procedure, to Miss P. Ratcliff, who carried out the ultracentrifugal analyses (in a machine generously donated by the Rockefeller Foundation of New York), and to Miss A. Hudson, who performed the Rose-Waaler titrations. Rheumatoid sera were kindly provided by Dr. C. F. Hawkins of the General Hospital, Birmingham.

Finally, we wish to acknowledge the generous financial assistance provided by the Empire Rheumatism Council.

\section{REFERENCES}

Ball, J. (1950). Lancet, 2, 520.

Fallet, G. H., Lospalluto, J., and Ziff, M. (1958). Arthr. and Rheum., 1, 419.

Franklin, E. C. (1960). Ibid., 3, 314.

Gell, P. G. H. (1957). J. clin. Path., 10, 67.

Grabar, P., and Williams, C. A. (1955). Biochim. biophys. Acta, 17, 67.

Grant, G. H., Rowe, D. S., and Stanworth, D. R. (1958). Biochem. J., 69, $13 \mathrm{P}$.

Heimer, R., Federico, O. M., Freyberg, R. (1958). Proc. Soc. exp. Biol. (N.Y.), 99, 381.

Kohn, J. (1959). Nature (Lond.), 183, 1055.

Kunkel, H. G. (1960). "Macroglobulins and High Molecular Weight Antibodies", in "The Plasma Proteins", ed. F. W. Putnam, vol. 1, chap. 8, pp. 279-307. Academic Press, New York and London.

—, Franklin, E. C., and Muller-Eberhard, H. J. (1959). J. clin. Invest., 38, 424.

Lever, W. F., Gurd, F. R. N., Uroma, E., Brown, R. K., Barnes, B. A., Schmid, K., and Schultz, E. L. (1951). Ibid., 30, 99.

Lospalluto, J., and Ziff, M. (1959). J. exp. Med., 110, 169.

Lowry, O. H., Rosebrough, N. J., Farr, A. Lewis, and Randall, R. J. (1951). J. biol. Chem., 193, 265.

Muller-Eberhard, H. J., and Kunkel, H. G. (1960). Fed. Proc., 19, No. 1, p. 76.

Peterson, E. A., and Sober, H. A. (1956). J. Amer. chem. Soc., 78, 751.

Rowe, D. S., and Soothill, J. F. (1961). Clin. Sci., 21, 76.

Soothill, J. F. (1961). Personal communication. 
Sober, H. A., Gutter, F. J., Wyckoff, M. M., and Peterson, E. A. (1956). J. Amer. chem. Soc., 78, 756.

Stanworth, D. R. (1959). Immunology, 2, 384.

- (1960). Nature (Lond.), 188, 156.

- James, K., and Squire, J. R. (1961). Analyt. Biochem. 2, 324.

Svartz, N. (1960). Acta med. scand., 168, 285.

—, Carlson, L. A., Schlossmann, K., and Ehrenberg, A. (1958). Ibid., $160,87$.

and Schlossmann, K. (1953). Ibid., 146, 313.

- - (1954). Ibid., 149, 83.

Ziff, M., Brown, P., Lospalluto, J., Badin, J., and McEwen, C. (1956). Amer. J. Med., 20, 500.

\section{Etudes sur l'isolement du facteur rhumatismal}

\section{RÉSUMÉ}

On analysa minutieusement les méthodes employées jusqu'à présent dans les tentatives d'isoler le facteur rhumatismal, telles que le fractionnement par précipitation de l'euglobuline, la chromatographie sur la cellulose DEAE (diéthylaminoéthyl), la centrifugation zonale et le fractionnement à l'éthanol en température basse d'après Cohn.

On détermina la récupération de l'activité sérologique et l'augmentation de l'activité spécifique. Le degré de resolution obtenue par de différents procédés fut étudié par des méthodes immunologiques et ultracentrifuges.

La manière la plus efficace pour préparer le facteur rhumatismal en un état assez pur semble être la précipitation de l'euglobuline par dilution aqueuse, suivie de centrifugation zonale.

Des méthodes impliquant la précipitation de l'euglobuine par une dialyse prolongée à l'eau ou par l'addition de sulfate d'ammonium concentré, la chromatographie sur la cellulose DEAE, et des procédés de concentration, telles que l'ultrafiltration et des procédés au glycol de polyéthylène, aboutirent à une perte considérable d'activité sérologique.

Avec des procédés employés jusqu'à présent il ne fut pas possible d'isoler la facteur rhumatismal et la globuline gamma $19 \mathrm{~S}$.

\section{Estudios sobre el aislamiento del factor reumatoide} SUMARIO

Se analizaron detalladamente los métodos empleados hasta ahora en las tentativas de aislar el factor reumatoide, tales como los procedimientos de fraccionamiento por precipitación de la euglobulina, cromatografía sobre celulosa DEAE (dietilaminoetil), centrifugación zonal y fraccionamiento por etanol en temperatura baja según Cohn.

Se determinó la recuperación de la actividad serológica y el aumento de la actividad específica. El grado de resolución por diversos procedimientos fué estudiado por métodos centrífugos e inmunológicos.

La más eficaz manera de preparar el factor reumatoide en un estado bastante puro parece ser la precipitación de euglobulina por dilución acuosa, seguida de centrifugación zonal.

Métodos que implican la precipitación de la euglobina por dialisis prolongada con agua or por añadidura de sulfato de amonio concentrado, la cromatografía sobre celulosa DEAE y procedimientos de concentración, tales como la ultrafiltración o el empleo de glicol de polietileno, ocasionaron una pérdida considerable de la actividad serológica.

Con los procedimientos empleados hasta la hora presente no fué posible resolver el factor reumatoide y la globulina gamma $19 S$. 